Jurnal Ilmu Hukum

FAKULTAS HUKUM UMSU

\title{
DUALISME PENGATURAN MENGENAI PEMBERHENTIAN PEGAWAI NEGERI SIPIL
}

\author{
Maria Arbina Tambun \\ Kantor Wilayah Kementerian Hukum dan HAM Sumatera Utara \\ Jl. Putri Hijau No.4 Kesawan, Medan - Sumatera Utara \\ Email: mariaarbina12@gmail.com
}

\begin{abstract}
Abstrak
Diundangkannya Undang-Undang Nomor 5 Tahun 2014 tentang Aparatur Sipil Negara dan Peraturan Pemerintah Nomor 11 Tahun 2017 tentang Manajemen Pegawai Negeri Sipil menimbulkan dualisme peraturan tentang pemberhentian pegawai negeri sipil. Karena selain kedua peraturan tersebut, Peraturan Pemerintah Nomor 53 Tahun 2010 tentang Disiplin Pegawai Negeri Sipil masih berlaku. Hal ini menimbulkan polemik, apakah pegawai negeri yang terlibat korupsi dikenakan hukuman berdasarkan Peraturan Pemerintah Nomor 53 Tahun 2010 tentang Disiplin Pegawai Negeri Sipil atau Peraturan Pemerintah Nomor 11 tahun 2017 tentang Pengelolaan Pegawai Negeri Sipil. Menanggapi polemik tersebut, putusan Mahkamah Konstitusi Nomor 87 / PUU-XVI / 2018 tentang Pengujian Undang-Undang Nomor 5 Tahun 2014 tentang Aparatur Sipil Negara yang dalam pertimbangannya menyatakan bahwa Pegawai Negeri Sipil dihukum karena melakukan pelanggaran pidana atau tindak pidana terkait dengan posisi tunduk pada pemberhentian yang tidak hormat sesuai dengan Peraturan Pemerintah Nomor 11 tahun 2017 tentang Pengelolaan Pegawai Negeri Sipil.
\end{abstract}

\section{Kata Kunci: Pemberhentian, Pegawai, Negeri, Sipil}

\section{Abstract}

The enactment of Law Number 5 Year 2014 on State Civil Apparatus and Government Regulation Number 11 of 2017 concerning Civil Servants Management raises a dualism of regulation regarding dismissal of civil servants. Because in addition to the two regulations, Government Regulation Number 53 of 2010 concerning Discipline of Civil Servants still applies. This raises a polemic, whether civil servants involved in corruption are subject to penalties based on Government Regulation Number 53 of 2010 concerning Discipline of Civil Servants or Government Regulation Number 11 of 2017 concerning Management of Civil Servants. Responding to the polemic, the Constitutional Court's decision No. 87 / PUU-XVI / 2018 concerning the Testing of Law Number 5 of 2014 concerning the State Civil Apparatus which in its consideration stated that Civil Servants were convicted of committing criminal offenses or related criminal acts with a position subject to a termination not respectfully in accordance with Government Regulation Number 11 of 2017 concerning Management of Civil Servants.

Keywords: Dismissal, Officer, State, Civil

\section{PENDAHULUAN}

Diundangkannya Undang-Undang Nomor 5 Tahun 2014 tentang Aparatur Sipil Negara, memberikan perubahan baru yang signifikan terkait dengan pengaturan Pegawai Negeri Sipil (PNS) yang berdasarkan undang-undang tersebut disebut sebagai Aparatur Sipil Negara. Salah satu perubahan yang signifikan adalah terkait dengan pemberhentian PNS. Jika dalam 
Jurnal Ilmu Hukum

FAKULTAS HUKUM UMSU
Dualisme Pengaturan Mengenai...(Maria Arbia Tambunan)

Volume 4 Nomor 1, Januari-Juni 2019, 54-62 DOI: https://doi.org/10.30596/dll.v4i1.3165

Undang-Undang Nomor 8 Tahun 1974 tentang Pokok-Pokok Kepegawaian jo Peraturan Pemerintah Nomor 53 Tahun 2010 tentang Disiplin Pegawai Negeri Sipil, pemberhentian PNS baik itu pemberhentian dengan hormat tidak atas permintaan sendiri sebagai PNSdan pemberhentian tidak dengan hormat sebagai PNSdiberikan sebagai hukuman atas pelanggaran disiplin tingkat berat.

Di dalam Undang-Undang Nomor 5 Tahun 2014 tentang Aparatur Sipil Negara pemberhentian PNS tidak berkaitan lagi dengan pelaksanaan disiplin pegawai negeri sipil yang terdiri dari disiplin ringan, sedang, dan berat. Pemberhentian PNS baik pemberhentian dengan hormat tidak atas permintaan sendiri maupun pemberhentian tidak dengan hormat sudah dibagi berdasarkan pelanggaran yang dilakukan. Sebagai contoh untuk pegawai yang dihukum penjara atau kurungan berdasarkan putusan pengadilan yang telah memiliki kekuatan hukum tetap karena melakukan tindak pidana kejahatan jabatan atau tindak pidana kejahatan yang ada hubungannya dengan jabatan seperti korupsi dijatuhi hukuman pemberhentian tidak dengan hormat.

Ketentuan lebih lanjut mengenai pemberhentian PNS yang diatur dalam UndangUndang Nomor 5 Tahun 2014 tentang Aparatur Sipil Negara diundangkan kemudian Peraturan Pemerintah Nomor 11 Tahun 2017 tentang Manajemen Pegawai Negeri Sipil. Peraturan Pemerintah Nomor 11 Tahun 2017 tentang Manajemen Pegawai Negeri Sipil mengatur juga mengenai pemberhentian pegawai negeri sipil. Uniknya, Peraturan Pemerintah Nomor 11 Tahun 2017 tentang Manajemen Pegawai Negeri Sipil tidak mencabut Peraturan Pemerintah Nomor 53 Tahun 2010 tentang Disiplin Pegawai Negeri Sipil yang juga mengatur mengenai pengenaan hukum disiplin termasuk di dalamnya pemberhentian PNS.

Kondisi tersebut menimbulkan dualisme pengaturan terkait dengan pemberhentian PNS. Hal ini tentunya menjadi menarik dikaji, terkait dengan penerapan hukuman kepada PNS yang melakukan tindak pidana korupsi, apakah dikenakan hukuman disiplin berat yaitu dapat diberhentikan dengan hormat tidak atas permintaan sendiri sebagai PNS dan pemberhentian tidak dengan hormat sebagai PNS sesuai dengan Peraturan Pemerintah Nomor 53 Tahun 2010 tentang Disiplin Pegawai Negeri Sipil atau dikenakan pemberhentian tidak dengan hormat sesuai dengan Peraturan Pemerintah Nomor 11 Tahun 2017 tentang Manajemen Pegawai Negeri Sipil.

\section{METODE PENELITIAN}

Penelitian ini merupakan penelitian hukum. Dengan jenis penelitian yang berlandaskan pada dokumen terkait atau bahan pustaka yang biasa disebut dengan penelitian normatif dengan bahan hukum sekunder. Penelitian normatif memadukan satu bahan pustaka dengan bahan pustaka lain atau peraturan yang berlaku sehingga dapat menghasilkan sebuah kesimpulan yang dapat dipahami oleh pembaca. Setelah semua bahan penelitian disatu padukan maka akan dianalisis dengan menggunakan metode kualitatif. 
DEIFGA LATA

Jurnal Ilmu Hukum

FAKULTAS HUKUM UMSU
Dualisme Pengaturan Mengenai...(Maria Arbia Tambunan) Volume 4 Nomor 1, Januari-Juni 2019, 54-62 DOI: https://doi.org/10.30596/dll.v4i1.3165

\section{PEMBAHASAN}

\section{Pemberhentian PNS Menurut Peraturan Pemerintah Nomor 53 Tahun 2010 Tentang Disiplin Pegawai Negeri Sipil}

Di dalam Peraturan Pemerintah Nomor 53 Tahun 2010 tentang Disiplin Pegawai Negeri Sipil, pemberhentian pegawai negeri sipil merupakan jenis hukuman disiplin berat sebagaimana diatur dalam Pasal 7 ayat 4 Peraturan Pemerintah Nomor 53 Tahun 2010 tentang Disiplin Pegawai Negeri Sipil. Ketentuan tersebut mengatur sebagai berikut:

Jenis hukuman disiplin berat sebagaimana dimaksud pada ayat 1 huruf c terdiri dari:

a. penurunan pangkat setingkat lebih rendah selama 3 (tiga) tahun

b. pemindahan dalam rangka penurunan jabatan setingkat lebih rendah

c. pembebasan dari jabatan

d. pemberhentian dengan hormat tidak atas permintaan sendiri sebagai PNS, dan

e. pemberhentian tidak dengan hormat sebagai PNS

Selain itu, untuk dapat dikenakan hukuman disiplin berat, ada beberapa jenis pelanggaran terhadap kewajiban yang dilanggar oleh PNS, yaitu:

a. Setia dan taat sepenuhnya kepada Pancasila dan Undang-Undang Dasar Negara Republik Indonesia Tahun 1945, Negara Kesatuan Republik Indonesia, dan Pemerintah sebagaimana dimaksud dalam Pasal 3 angka 3 Peraturan Pemerintah Nomor 53 Tahun 2010 tentang Disiplin Pegawai Negeri Sipil, apabila pelanggaran berdampak negatif pada pemerintah dan/atau negara

b. Menaati segala ketentuan peraturan perundangundangan sebagaimana dimaksud dalam Pasal 3 angka 4 Peraturan Pemerintah Nomor 53 Tahun 2010 tentang Disiplin Pegawai Negeri Sipil, apabila pelanggaran berdampak negatif pada pemerintah dan/atau negara;

c. Melaksanakan tugas kedinasan yang dipercayakan kepada PNS dengan penuh pengabdian, kesadaran, dan tanggung jawab sebagaimana dimaksud dalam Pasal 3 angka 5 Peraturan Pemerintah Nomor 53 Tahun 2010 tentang Disiplin Pegawai Negeri Sipil, apabila pelanggaran berdampak negatif pada pemerintah dan/atau negara;

d. Menjunjung tinggi kehormatan negara, pemerintah, dan martabat PNS sebagaimana dimaksud dalam Pasal 3 angka 6 Peraturan Pemerintah Nomor 53 Tahun 2010 tentang Disiplin Pegawai Negeri Sipil, apabila pelanggaran berdampak negatif pada pemerintah dan/atau negara

e. Mengutamakan kepentingan negara daripada kepentingan sendiri, seseorang, dan/atau golongan sebagaimana dimaksud dalam Pasal 3 angka 7 Peraturan Pemerintah Nomor 53 Tahun 2010 tentang Disiplin Pegawai Negeri Sipil, apabila pelanggaran berdampak negatif pada pemerintah dan/atau negara

f. Memegang rahasia jabatan yang menurut sifatnya atau menurut perintah harus dirahasiakan sebagaimana dimaksud dalam Pasal 3 angka 8 Peraturan Pemerintah Nomor 53 Tahun 2010 tentang Disiplin Pegawai Negeri Sipil, apabila pelanggaran berdampak negatif pada pemerintah dan/atau negara 
Jurnal Ilmu Hukum

FAKULTAS HUKUM UMSU
Dualisme Pengaturan Mengenai...(Maria Arbia Tambunan)

Volume 4 Nomor 1, Januari-Juni 2019, 54-62 DOI: https://doi.org/10.30596/dll.v4i1.3165

g. bekerja dengan jujur, tertib, cermat, dan bersemangat untuk kepentingan negara sebagaimana dimaksud dalam Pasal 3 angka 9 Peraturan Pemerintah Nomor 53 Tahun 2010 tentang Disiplin Pegawai Negeri Sipil, apabila pelanggaran berdampak negatif pada pemerintah dan/atau negara

h. melaporkan dengan segera kepada atasannya apabila mengetahui ada hal yang dapat membahayakan atau merugikan negara atau Pemerintah terutama di bidang keamanan, keuangan, dan materiil sebagaimana dimaksud dalam Pasal 3 angka 10 Peraturan Pemerintah Nomor 53 Tahun 2010 tentang Disiplin Pegawai Negeri Sipil, apabila pelanggaran berdampak negatif pada pemerintah dan/atau negara

i. masuk kerja dan menaati ketentuan jam kerja sebagaimana dimaksud dalam Pasal 3 angka 11 Peraturan Pemerintah Nomor 53 Tahun 2010 tentang Disiplin Pegawai Negeri Sipil berupa:

1) Penurunan pangkat setingkat lebih rendah selama 3 (tiga) tahun bagi PNS yang tidak masuk kerja tanpa alasan yang sah selama 31 (tiga puluh satu) sampai dengan 35 (tiga puluh lima) hari kerja

2) Pemindahan dalam rangka penurunan jabatan setingkat lebih rendah bagi PNS yang menduduki jabatan struktural atau fungsional tertentu yang tidak masuk kerja tanpa alasan yang sah selama 36 (tiga puluh enam) sampai dengan 40 (empat puluh) hari kerja

3) Pembebasan dari jabatan bagi PNS yang menduduki jabatan struktural atau fungsional tertentu yang tidak masuk kerja tanpa alasan yang sah selama 41 (empat puluh satu) sampai dengan 45 (empat puluh lima) hari kerja, dan

4) Pemberhentian dengan hormat tidak atas permintaan sendiri atau pemberhentian tidak dengan hormat sebagai PNS bagi PNS yang tidak masuk kerja tanpa alasan yang sah selama 46 (empat puluh enam) hari kerja atau lebih

j. Mencapai sasaran kerja pegawai yang ditetapkan sebagaimana dimaksud dalam Pasal 3 angka 12 Peraturan Pemerintah Nomor 53 Tahun 2010 tentang Disiplin Pegawai Negeri Sipil, apabila pencapaian sasaran kerja pegawai pada akhir tahun kurang dari $25 \%$ (dua puluh lima persen)

k. Menggunakan dan memelihara barang-barang milik negara dengan sebaik-baiknya sebagaimana dimaksud dalam Pasal 3 angka 13 Peraturan Pemerintah Nomor 53 Tahun 2010 tentang Disiplin Pegawai Negeri Sipil, apabila pelanggaran berdampak negatif pada pemerintah dan/atau negara

1. Memberikan pelayanan sebaik-baiknya kepada masyarakat sebagaimana dimaksud dalam Pasal 3 angka 14 Peraturan Pemerintah Nomor 53 Tahun 2010 tentang Disiplin Pegawai Negeri Sipil, sesuai dengan ketentuan peraturan perundang-undangan, dan

m. Menaati peraturan kedinasan yang ditetapkan oleh pejabat yang berwenang sebagaimana dimaksud dalam Pasal 3 angka 17 Peraturan Pemerintah Nomor 53 Tahun 2010 tentang Disiplin Pegawai Negeri Sipil, apabila pelanggaran berdampak negatif pada pemerintah dan/atau negara.

Selain pelanggaran terhadap kewajiban, PNS juga dikenakan hukuman disiplin berat 
Jurnal Ilmu Hukum

FAKULTAS HUKUM UMSU
Dualisme Pengaturan Mengenai...(Maria Arbia Tambunan)

Volume 4 Nomor 1, Januari-Juni 2019, 54-62 DOI: https://doi.org/10.30596/dll.v4i1.3165

terhadap jika melakukan pelanggaran terhadap larangan sebagai berikut:

a. Menyalahgunakan wewenang sebagaimana dimaksud dalam Pasal 4 angka 1

b. Menjadi perantara untuk mendapatkan keuntungan pribadi dan/atau orang lain dengan menggunakan kewenangan orang lain sebagaimana dimaksud dalam Pasal 4 angka 2

c. Tanpa izin Pemerintah menjadi pegawai atau bekerja untuk negara lain dan/atau lembaga atau organisasi internasional sebagaimana dimaksud dalam Pasal 4 angka 3

d. Bekerja pada perusahaan asing, konsultan asing, atau lembaga swadaya masyarakat asing sebagaimana dimaksud dalam Pasal 4 angka 4;

e. Memiliki, menjual, membeli, menggadaikan, menyewakan, atau meminjamkan barangbarang baik bergerak atau tidak bergerak, dokumen atau surat berharga milik negara secara tidak sah sebagaimana dimaksud dalam Pasal 4 angka 5, apabila pelanggaran berdampak negatif pada pemerintah dan/atau negara;

f. Melakukan kegiatan bersama dengan atasan, teman sejawat, bawahan, atau orang lain di dalam maupun di luar lingkungan kerjanya dengan tujuan untuk keuntungan pribadi, golongan, atau pihak lain, yang secara langsung atau tidak langsung merugikan negara sebagaimana dimaksud dalam Pasal 4 angka 6, apabila pelanggaran berdampak negatif pada pemerintah dan/atau negara;

g. Memberi atau menyanggupi akan memberi sesuatu kepada siapapun baik secara langsung atau tidak langsung dan dengan dalih apapun untuk diangkat dalam jabatan sebagaimana dimaksud dalam Pasal 4 angka 7;

h. Menerima hadiah atau suatu pemberian apa saja dari siapapun juga yang berhubungan dengan jabatan dan/atau pekerjaannya sebagaimana dimaksud dalam Pasal 4 angka 8;

i. Melakukan suatu tindakan atau tidak melakukan suatu tindakan yang dapat menghalangi atau mempersulit salah satu pihak yang dilayani sehingga mengakibatkan kerugian bagi yang dilayani sebagaimana dimaksud dalam Pasal 4 angka 10, sesuai dengan ketentuan peraturan perundangundangan;

j. Menghalangi berjalannya tugas kedinasan sebagaimana dimaksud dalam Pasal 4 angka 11, apabila pelanggaran berdampak negatif pada pemerintah dan/atau negara;

k. Memberikan dukungan kepada calon Presiden/Wakil Presiden, Dewan Perwakilan Rakyat, Dewan Perwakilan Daerah, atau Dewan Perwakilan Rakyat Daerah dengan cara sebagai peserta kampanye dengan menggunakan fasilitas negara, sebagaimana dimaksud dalam Pasal 4 angka 12 huruf d;

1. Memberikan dukungan kepada calon Presiden/Wakil Presiden dengan cara membuat keputusan dan/atau tindakan yang menguntungkan atau merugikan salah satu pasangan calon selama masa kampanye sebagaimana dimaksud dalam Pasal 4 angka 13 huruf a; dan

m. Memberikan dukungan kepada calon Kepala Daerah/Wakil Kepala Daerah, dengan cara menggunakan fasilitas yang terkait dengan jabatan dalam kegiatan kampanye dan/atau membuat keputusan dan/atau tindakan yang menguntungkan atau merugikan salah satu pasangan calon selama masa kampanye sebagaimana dimaksud dalam Pasal 4 angka 15 huruf $\mathrm{b}$ dan huruf $\mathrm{c}$. 
DE LEGA LATA

Jurnal Ilmu Hukum

FAKULTAS HUKUM UMSU
Dualisme Pengaturan Mengenai...(Maria Arbia Tambunan)

Volume 4 Nomor 1, Januari-Juni 2019, 54-62

DOI: https://doi.org/10.30596/dll.v4i1.3165

\section{Pemberhentian PNS Menurut Peraturan Pemerintah Nomor 11 Tahun 2017 Tentang Manajemen Pegawai Negeri Sipil}

Berbeda dengan pengaturan dalam Peraturan Pemerintah Nomor 53 Tahun 2010 tentang Disiplin Pegawai Negeri Sipil, dalam Peraturan Pemerintah Nomor 11 Tahun 2017 tentang Manajemen Pegawai Negeri Sipil, dikenal beberapa jenis pemberhentian PNS, yaitu:

a. Pemberhentian Atas Permintaan Sendiri. Permintaan berhenti atas permintaan sendiri ditolak apabila:

1) Sedang dalam proses peradilan karena didugamelakukan tindak pidana kejahatan;

2) Terikat kewajiban bekerja pada instansipemerintah berdasarkan ketentuan peraturanperundang-undangan;

3) Dalam pemeriksaan pejabat yang berwenangmemeriksa karena diduga melakukan pelanggarandisiplin pns;

4) Sedang mengajukan upaya banding administratifkarena dijatuhi hukuman disiplin berupapemberhentian dengan hormat tidak ataspermintaan sendiri sebagai pns;

5) Sedang menjalani hukuman disiplin dan/ atau alasan lain menurut pertimbangan PPK.

b. Pemberhentian Karena MencapaiBatas Usia Pensiun. Batas Usia Pensiun yaitu:

1) 58 (lima puluh delapan) tahun bagi pejabatadministrasi, pejabat fungsional ahli muda,pejabat fungsional ahli pertama, dan pejabatfungsional keterampilan;

2) 60 (enam puluh) tahun bagi pejabat pimpinantinggi dan pejabat fungsional madya; dan

3) 65 (enam puluh lima) tahun bagi PNS yangmemangku pejabat fungsional ahli utama.

c. Pemberhentian karena Perampingan Organisasiatau Kebijakan Pemerintah. Dalam hal terjadi perampingan organisasi ataukebijakan pemerintah yang mengakibatkan kelebihanPNS maka PNS tersebut terlebih dahulu disalurkanpada Instansi Pemerintah lain. Akan tetapi, dalam hal terdapat PNS yang bersangkutan tidakdapat disalurkan dan pada saat terjadi perampingan organisasisudah mencapai usia 50 (lima puluh) tahun dan masa kerja 10 (sepuluh) tahun, diberhentikan denganhormat dengan mendapat hak kepegawaian sesuaidengan ketentuan peraturan perundang-undangan.

d. Pemberhentian Karena Tidak CakapJasmani dan/ atau Rohani. PNS yang tidak cakap jasmani dan/ataudiberhentikan dengan hormat apabila:

1) Tidak dapat bekerja lagi dalam semuakarena kesehatannya;

2) Menderita penyakit atau kelainan yang berbahayabagi dirinya sendiri atau lingkungan kerjanya;atau

3) Tidak mampu bekerja kembali setelah berakhirnyacuti sakit.

e. Pemberhentian Karena Meninggal Dunia,Tewas, atau Hilang

f. Pemberhentian karena MelakukanTindak Pidana/ Penyelewengan.

1) PNS dapat diberhentikan dengan hormat atau tidakdiberhentikan karena dihukum penjara berdasarkanputusan pengadilan yang telah memiliki kekuatanhukum tetap karena melakukan tindak pidana denganhukuman pidana penjara paling singkat 2 (dua) tahundan pidana yang dilakukan tidak berencana.PNS yang dipidana dengan pidana penjara 2 (dua)tahun atau lebih berdasarkan putusan pengadilanyang telah memiliki 
kekuatan hukum tetap karenamelakukan tindak pidana tidak dengan berencana,tidak diberhentikan sebagai PNS apabila:

a) perbuatannya tidak menurunkan harkat danmartabat dari PNS;

b) mempunyai prestasi kerja yang baik;

c) tidak mempengaruhi lingkungan kerja setelahdiaktifkan kembali; dan

d) tersedia lowongan Jabatan

2) PNS diberhentikan tidak dengan hormat apabila:

a) Melakukan penyelewengan terhadap Pancasila danundang-Undang Dasar Negara Republik indonesiatahun 1945;

b) Dipidana dengan pidana penjara atau kurunganberdasarkan putusan pengadilan yang telah memilikikekuatan hukum tetap karena melakukan tindakpidana kejahatan Jabatan atau tindak pidanakejahatan yang ada hubungannya dengan Jabatandan/ atau pidana umum;

c) Menjadi anggota dan/atau pengurus partai politik;atau

d) Dipidana dengan pidana penjara berdasarkanputusan pengadilan yang telah memiliki kekuatanhukum tetap karena melakukan tindak pidanadengan hukuman pidana penjara paling singkat2 (dua) tahun dan pidana yang dilalukan denganberencana.

\section{Pemberhentian Pegawai Negeri Sipil Yang Terlibat Korupsi}

Jika menggunakan asas hukum lex superior derogate legi inferior, terhadap PNS yang terlibat korupsi jelas dikenakan pemberhentian tidak dengan hormat sesuai dengan ketentuan Pasal 87 ayat (4) Undang-Undang Nomor 5 Tahun 2014 tentang Aparatur Sipil Negara. Akan tetapi, dengan masih berlakunya Peraturan Pemerintah Nomor 53 Tahun 2010 tentang Disiplin Pegawai Negeri Sipil, terbuka kemungkinan terhadap PNS yang terlibat korupsi hanya dikenakan pemberhentian dengan hormat tidak atas permintaan sendiri. Oleh karena itu, seyogianya perlu pengaturan yang jelas mengenai tindakan yang dilakukan terhadap pegawai negeri sipil yang terlibat korupsi.

Terkait dengan hal tersebut, polemik ini kemudian menjadi jelas dengan keluarnya Putusan Mahkamah Konstitusi Nomor 87/PUU-XVI/2018 mengenai Pengujian UndangUndang Nomor 5 Tahun 2014 tentang Aparatur Sipil Negara. Dalam pertimbangannya, Mahkamah Konstitusi menyatakan sebagai berikut:

... terkait dengan pemberhentian Pegawai Negeri Sipil karena dihukum penjara atau kurungan berdasarkan putusan pengadilan yang telah memiliki kekuatan hukum tetap karena melakukan tindak pidana kejahatan jabatan atau tindak pidana yang ada hubungannya dengan jabatan, hal demikian adalah wajar sebab dengan melakukan kejahatan atau tindak pidana demikian seorang pegawai negeri sipil telah menyalahgunakan atau bahkan mengkhianati jabatan yang dipercayakan kepadanya untuk diemban sebagai aparatur sipil negara. Sebab, seorang PNS yang melakukan kejahatan atau tindak pidana demikian sesungguhnya, secara langsung atau tidak langsung, telah mengkhianati rakyat karena perbuatan demikian telah menghambat upaya mewujudkan cita-cita atau tujuan bernegara yang seharusnya menjadi acuan 
Jurnal Ilmu Hukum

FAKULTAS HUKUM UMSU
Dualisme Pengaturan Mengenai...(Maria Arbia Tambunan)

Volume 4 Nomor 1, Januari-Juni 2019, 54-62 DOI: https://doi.org/10.30596/dll.v4i1.3165

utama bagi seorang PNS sebagai ASN dalam melaksanakan tugas-tugasnya, baik tugas pelayanan publik, tugas pemerintahan, ataupun tugas pembangunan tertentu.

Putusan Mahkamah Konstitusi Nomor 87/PUU-XVI/2018 mengenai Pengujian UndangUndang Nomor 5 Tahun 2014 tentang Aparatur Sipil Negara, menegaskan bahwa terhadap Pegawai Negeri Sipil yang melakukan tindak pidana jabatan atau tindak pidana yang berkaitan dengan jabatannya sudah wajar dikenakan pemberhentian tidak dengan hormat. Putusan ini kemudian dianggap sebagai jalan keluar adanya dualisme pengenaan sanksi terhadap PNS yang melakukan tindak pidana jabatan seperti korupsi.

\section{KESIMPULAN DAN SARAN}

\section{Kesimpulan}

Diundangkannya Undang-Undang Nomor 5 Tahun 2014 tentang Aparatur Sipil Negara dan Peraturan Pemerintah Nomor 11 Tahun 2017 tentang Manajemen Pegawai Negeri Sipil, telah menimbulkan dualism pengaturan mengenai pemberhentian PNS. Hal tersebut dikarenakan masih berlakunya Peraturan Pemerintah Nomor 53 Tahun 2010 tentang Disiplin Pegawai Negeri Sipil. Terkait dengan PNS yang terlibat atau melakukan tindak pidana korupsi, timbul polemik apakah akan dikenakan hukuman sesuai dengan Peraturan Pemerintah Nomor 53 Tahun 2010 tentang Disiplin Pegawai Negeri Sipil, yaitu diberhentikan dengan hormat atas permintaan sendiri atau diberhentikan tidak dengan hormat karena melanggar disiplin berat, atau dikenakan hukuman sesuai Peraturan Pemerintah Nomor 11 Tahun 2017 tentang Manajemen Pegawai Negeri Sipil, yaitu diberhentikan tidak dengan hormat.

Polemik ini kemudian selesai dengan keluarnya Putusan Mahkamah Konstitusi Nomor 87/PUU-XVI/2018 tentang Pengujian Undang-Undang Nomor 5 Tahun 2014 tentang Aparatur Sipil Negara, yang dalam pertimbangan hukumnya menyatakan bahwa terhadap pegawai negeri sipil yang dihukum karena melakukan tindak pidana jabatan atau tindak pidana terkait dengan jabatan dikenakan hukum diberhentikan tidak dengan hormat.

\section{Saran}

Terjadinya dualism peraturan atau hukum yang berbeda seharusnya dapat diselesaikan dengan melakukan Judicial Review ke Mahkamah Konstitusi, dengan begitu MK dalam hal ini yang memiliki kewenangan maka akan memutuskan peraturan mana atau hukuman mana yang akan digunakan. 


\section{DAFTAR PUSTAKA}

Undang-Undang Nomor 5 Tahun 2014 tentang Aparatur Sipil Negara.

Peraturan Pemerintah Nomor 53 Tahun 2010 tentang Disiplin Pegawai Negeri Sipil.

Peraturan Pemerintah Nomor 11 Tahun 2017 tentang Manajemen Pegawai Negeri Sipil.

Putusan Mahkamah Konstitusi Nomor 87/PUU-XVI/2018 tentang Pengujian Undang-Undang Nomor 5 Tahun 2014 tentang Aparatur Sipil Negara. 